\title{
EDUCATIONAL INEQUALITIES IN SELF-RATED HEALTH: WHETHER POST-SOCIALIST ESTONIA AND RUSSIA ARE PERFORMING BETTER THAN 'SCANDINAVIAN' FINLAND
}

\author{
Rein Vöörmann, Jelena Helemäe \\ Department of Social Stratification, Institute for International and Social Studies, Tallinn University, Tallinn, Estonia
}

\begin{abstract}
SUMMARY
Aim: The aim of the study is to analyse relationship between self-rated health (SRH) and education in post-socialist countries (Estonia and Russia) and in Finland, a Scandinavian country.

Methods: Data from the 5 th wave of the European Social Survey (ESS) carried out in 2010 were used. In particular, we used a sub-sample of the 25-69 years old. Two-step analysis was carried out: descriptive overview of relationship between SRH and education to assess the knowledge-related impact of education on SRH in pooled model for all three countries; and logistic regression analysis to evaluate separate models in each country.

Results: The prevalence of at-least-good health was the highest in Finland, Estonia occupied the second position and Russia the third. Knowledge-related educational inequalities were lower in Russia compared to Finland, while they were of similar magnitude in Estonia and Finland.

Conclusions: Our expectations that knowledge-based inequalities are lower in post-socialist countries compared to a Scandinavian country turn to be true in case of Russia, not Estonia. Possible reasons for the expectations might be a lack of attention paid to educational inequalities in terms of access to social resources, competitiveness in the labour market and to what extent education provide a tool against uncertainty (preventing work- and unemployment-related stress). Series of comparative studies revealing links between certain institutional packages and (socio-economic and knowledge-related) educational inequalities seem to be of special relevance.
\end{abstract}

Key words: Estonia, Russia, Finland, education, self-rated health, post-socialist welfare system, Scandinavian welfare system

Address for correspondence: R. Vö̈rmann, Department of Social Stratification, Institute for International and Social Studies, Tallinn University, Uus Sadama 5, 10120 Tallinn, Estonia. E-mail: voormann@iiss.ee

\section{INTRODUCTION}

In the last three decades, such measures of socio-economic status as income, work position and education have been proved to underpin the statistical dispersion of different health outcomes (1). Many studies rely on education as the main determinant of a hierarchical position in society. In addition, education is a personal quality linked to different kind of opportunities and outcomes in life (2-4). Education indirectly (socio-economically) affects health outcomes through its association with economic resources, productive activities (economic effect) and social network (social effect). At the same time education might have direct effect on health outcomes through the access to knowledge resources and skills (knowledge-related effect): the acquisition of knowledge regarding healthy life styles or health damaging behaviours or opportunities and rights in terms of access to health services, the ability to optimise use of health services, etc. (5-7). Indeed, previous studies have shown that higher education predicts better health, while less educated people have an increased risk of poor health and have less healthy lifestyles $(8,9)$.

Within the past decade, considerable effort has been made to understand how contextual (i.e. country-level) factors such as political systems and government policies contribute to health inequalities (10-12). Particularly, ample variations across nations in the educational health gap have been found $(4,13)$. The variations were attributed to peculiarities of welfare state (14), different extent of social openness of societies (15), crossnational variations in health expenditure and labour market outcomes (4). But all in all, so far little is known on the causal interactions between the welfare state regulation and individual health (16), particularly about the way how these regulations mediate socio-economic and knowledge-related impacts of education on health. Research testing cross-national differences in the association between education and health is still lacking (4). One unexpected result of comparative studies was that health inequalities in Scandinavian social democratic countries are not consistently smaller than under other welfare regimes (17). These results were discussed as so-called 'Scandinavian paradox' (18). Particular appearance of this paradox was revealed by Eikemo et al. - in terms of educational health inequality, countries in the Scandinavian welfare regime were ranked less favourable than those in the Anglo-Saxon and Eastern European regimes (14).

Moving beyond a high level of aggregation (such as type of welfare regime) was proposed as one of possible ways of resolving this paradox, because differences within a cluster of Scandinavian 
welfare regimes are well-recognized (18). There is a growing awareness about huge variation between post-socialist regimes as well. These countries exhibit a remarkable diversity in approaches to economic reforms and emergent institutions (19), making their consideration under common 'post-socialist' umbrella rather questionable. In this paper we focus on comparison of small number of countries, namely Finland as a Scandinavian country with Estonia and Russia as representatives of post-socialist Eastern regimes. We approach the issue of unfavourable situation of educational health inequalities in Scandinavian social-democratic welfare regime compared with post-socialist Eastern European regime by distinguishing between indirect socio-economic and direct knowledge-related impact of education on health in three countries. We suggest that welfare state through its redistributional institutions and policies in general and particularly through health policies shapes first of all socio-economic educational health inequalities, setting in this way limits for application of healthrelated knowledge and skills, particularly for choice of healthy lifestyle (knowledge-related educational health inequalities). Under welfare regimes with poor equalization measures and poor provision of public health services (liberal and some postsocialist welfare regimes), educational inequalities in health are expected to be rather of compounding nature so that knowledgerelated inequalities coincide with socio-economic ones. Under socio-democratic welfare regimes with low socio-economic inequalities and adequate provision of public health services we expect the knowledge-related component of educational health inequalities to be of greater importance compared with liberal and some post-socialist regimes. So, we suggest that these are first of all knowledge-related educational health inequalities that are lower in liberal and some post-socialist countries compared to Scandinavian countries.

All three countries: Estonia, Russia and Finland, are neighbours in geographical terms, but with a very different historical background, not speaking about the economy, population size etc. Estonia and Finland are culturally close, while Russia is often presented as totally different (20). After the collapse of the socialist system, Russia and Estonia experienced transition from state socialism to (quite different variations of) capitalism which in turn differs from Finland's one. In these countries current level of economic and social development, particularly extent of social inequality differs substantially, so that Estonia (together with other Baltic states) is characterized as the least 'Scandinavian' in the East European region (21). The latter seems to apply to the Russian Federation as well. Public expenditures on health as percentage of gross domestic product in Finland (8.8) is higher compared to both Estonia (6.1) and Russia (4.8) (22). Thus, we expect that population at large in Scandinavian-regime's Finland has better self-perceived health compared to Russia and Estonia, where socio-economic aspect of educational health inequalities is suggested to coincide with knowledge-related one, so that net of financial and/or employment inequalities, knowledge-related educational health inequalities are rather weak and lower compared with Finland.

The aim of this paper is to study association between SRH and education and to explore whether knowledge-related educational inequalities in self-rated health (SRH) in Estonia and Russia as post-socialist countries are lower than in Scandinavian Finland.

\section{MATERIALS AND METHODS}

\section{Data}

We used data from the fifth wave of the European Social Survey (ESS) carried out in 2010 in 28 countries including Estonia, Russia and Finland (24). Samples of participating countries have comparable estimates based on full coverage of the eligible residential population aged 15 years and older. The size of samples was in Estonia - 3,336 (addresses, households or individuals), in Russia 3,982 and in Finland 3,200. The response rate was 56.2; 59.5 and $66.6 \%$, respectively (25). In this paper we used a subsample of 25-69 year old population of ESS. Persons under 25 years of age were not included because many of them have not yet completed their degree. The upper age limit was used because of chronic diseases emerging after that age. Final number of records in data file was 1,216 for Estonia, 1,847 and 1,335 for Russia and Finland, respectively.

\section{Measures}

The status of SRH was derived from the response to the question - "How is your health in general?" with the options "very good', 'good', 'fair', 'poor', 'very poor' (26-28). In the analysis SRH variable was dichotomized as at-least-good (very good or good) health and less-than-good (fair, poor or very poor) health.

Education levels were categorized according to the International Standard Classification of Education (ISCED) scale: 'basic' means ISCED categories from 0 to 2 (also Vocational ISCED $3 \mathrm{C}<2$ years), 'secondary' - ISCED categories 3, 4 and 5A short, also 5B short, and 'higher' - ISCED categories from ISCED 5A medium to ISCED 6.

Socio-economic position was measured by employment status and financial situation widely recognized as crucial factors of health outcomes (29). Measure 'employment status' takes into account whether respondent works or not. For employed person occupational class is distinguished (white-collars versus bluecollars). Financial situation was measured by subjective estimation - how individual feels about her/his household income. We preferred this measure to increase response rate significantly since amount of income may not differentiate people retired from the labour market in the same way as prime age population (30). Self-rated financial situation was classified as good and poor.

Age, marital status and type of residence were used as control variables in the analysis. Age was divided into three groups: 25-39, 40-54, 55-69. Two types of marital status were distinguished, first - married or cohabiting; second - divorced, separated or widowed, single. Type of residence was categorized as living in big cities (more than 100,000 inhabitants), other towns, and rural areas.

\section{Data Analysis}

We carried out a two-step analysis. The first step included descriptive overview of relationship between SRH and education (Table 1). Secondly, logistic regression (LR) analysis was applied separately for men and women to assess the impact of education on SRH in pooled model for all three countries and separately in each of three examined countries. The risk of perceiving own health to be less-than-good was the dependent 
variable. To discern knowledge-related impact of education on that risk we distinguished between "gross" and "net" effect of education. Odds ratios (OR) from the LR model with education as single variable were referred to as "gross" effect. OR from model with the education and controls (age, marital status and place of residence) were referred to as adjusted gross effect of education (combining both socio-economic and knowledge-related aspects). OR from models that include education, controls and also employment status and self-rated financial situation of respondents were referred to as "net" effect of education, i.e. knowledge-related effect of education: here socio-economic effect of education was eliminated due to inclusion of employment status and financial situation into the model.

Pooled data set was used to assess if gross, adjusted gross and net impacts of education differ among Estonia, Finland and Russia. Thereby, indicator of being resident of country and interaction terms between country and education were included into the LR models (Table 2).

To reveal gross, adjusted gross and net (direct) effect of education on SRH, LR models were estimated for each country for men and women separately (Table 3 ).

\section{RESULTS}

The most general picture concerning Estonia, Russia and Finland in relationship to estimation of self-rated health is demonstrated in Table 1.
It appears that Finland occupies the first position while Estonia the second and Russia the third one. In the other end of scale (assessing health situation as very poor or poor), the distribution of respondents was the other way round: the largest share of respondents represented Russia, followed by Estonia and Finland.

As regard to the level of education, this was the highest in Russia (the highest proportion of people with higher education), and the lowest in Finland (the highest share of people with basic education).

Our data also show that the SRH depends on the education level: more educated people have usually better health and vice versa. Finland performed better than both post-socialist countries, however, in Finland gaps between educational groups in terms of SRH were wider compared with Russia, but about the same as in Estonia.

This conclusion was supported by results of LR analysis (Table 2).

Interaction terms between country and education were presented as estimations for three models: Model 1 included only country and education variables and their interaction; Model 2 included also controls (age, type of residence and marital status); and Model 3 employment status and self-rated financial situation as measures of socio-economic status as well. Residents of Finland and persons with higher education were relative reference groups. Similarity between Estonia and Finland was revealed by all three models: all interaction terms were non-significant for both women and men alike. Comparison of Russia with Finland revealed more complex picture. Significant interaction terms in Model 1 (gross

Table 1. Self-rated health in 25-69 year old men and women in Estonia, Russia and Finland (European Social Survey)

\begin{tabular}{|l|c|c|c|c|c|c|c|c|c|}
\hline \multirow{2}{*}{ Self-rated health } & \multicolumn{3}{|c|}{ Estonia } & \multicolumn{3}{c|}{ Russia } & \multicolumn{3}{c|}{ Finland } \\
\cline { 2 - 12 } & Female & Male & Total & Female & Male & Total & Female & Male & Total \\
\hline Very good & 8 & 10 & 9 & 2 & 5 & 3 & 25 & 19 & 22 \\
\hline Good & 39 & 37 & 38 & 26 & 39 & 32 & 44 & 46 & 45 \\
\hline Fair & 45 & 47 & 46 & 61 & 49 & 56 & 27 & 26 & 27 \\
\hline Poor & 7 & 5 & 6 & 10 & 6 & 8 & 3 & 7 & 5 \\
\hline Very poor & 1 & 1 & 1 & 1 & 1 & 2 & 1 & 2 & 1 \\
\hline Total & 100 & 100 & 100 & 100 & 100 & 100 & 100 & 100 & 100 \\
\hline N & 713 & 503 & 1,216 & 1,050 & 797 & 1,847 & 648 & 687 & 1,335 \\
\hline
\end{tabular}

Values in \%

Table 2. Impact of education on less-than-good self-rated health in 25-69 year old men and women in Estonia, Russia and Finland: odds ratios for two-way interaction (European Social Survey 2010)

\begin{tabular}{|c|c|c|c|c|c|c|c|}
\hline & & \multicolumn{3}{|c|}{ Female } & \multicolumn{3}{|c|}{ Male } \\
\hline & & Model 1 & Model 2 & Model 3 & Model 1 & Model 2 & Model 3 \\
\hline \multirow{2}{*}{ Estonia $^{a}$} & Basic education ${ }^{a}$ & 0.66 & 1.26 & 1.04 & 0.77 & 1.00 & 0.97 \\
\hline & Secondary education & 0.75 & 0.98 & 0.80 & 0.64 & 0.68 & 0.70 \\
\hline \multirow{2}{*}{ Russia $^{a}$} & Basic education & $0.21^{* * *}$ & 0.40 & $0.27^{*}$ & $0.40^{*}$ & 0.51 & 0.44 \\
\hline & Secondary education & $0.49^{*}$ & 0.56 & $0.45^{*}$ & $0.50^{*}$ & $0.50^{*}$ & $0.42^{* *}$ \\
\hline \multicolumn{2}{|l|}{$\mathrm{R}^{2}$} & $0.217^{\star * *}$ & $0.311^{* * *}$ & $0.354^{* * *}$ & $0.097^{* * *}$ & $0.214^{* * *}$ & $0.252^{* * *}$ \\
\hline
\end{tabular}

Model 1: Country, education and interaction terms between country and education

Model 2: Model $1+$ control variables (age, marital status, place of residence)

Model 3: Model 2 + socio-economic status measures (employment status and self-rated financial situation)

a Finland is reference group for countries and higher education is reference group for education

${ }^{*} p<0.05,{ }^{* *} p<0.01,{ }^{* * *} p<0.001$ 
educational inequalities) turned to be insignificant (except for OR for Russia secondary education) in Model 2 (adjusted gross educational inequalities). According to estimations of Model 2 (not presented here but available upon request), this difference in results between Models 1 and 2 was explained first of all by the main effect of age, i.e. what seemed to be educational inequality turned to be rather indirect outcome of age inequalities in SRH. Model 3 showed once again that educational disparities (this time net ones) in Russia were smaller than in Finland. It means that for both men and women in Russia education differentiates SRH of people of the same socio-demographic status and in the similar socio-economic position to a less extent than in Finland.

Additional analysis of Model 3 (not presented but available upon request) showed that the net risks to perceive less-than- good health were significantly higher in Estonia than in Finland. In Russia, all educational groups experience very high risks of less-than-good self-reported health compared to Finland. Thus, lower net educational health inequalities in Russia compared to Finland mean that the situation was equally highly risky for the whole Russian population, while the biggest difference in probabilities of less-than-good SRH was between Russians and Finns (especially women) with higher education.

Table 3 demonstrates results of investigation of countryspecific patterns of educational health inequalities.

Estimations in Model 1 were in line with the above reported results revealing existence of gross impact of education on SRH in each country for both men and women, while there is a variation in magnitude of this impact (being lowest for men in Russia

Table 3. Impact of education on less-than-good self-rated health in 25-69 year old men and women in Estonia, Russia and Finland, odds ratios (European Social Survey)

\begin{tabular}{|c|c|c|c|c|c|c|}
\hline & \multicolumn{3}{|c|}{ Female } & \multicolumn{3}{|c|}{ Male } \\
\hline & Model 1 & Model 2a & Model $3^{\mathrm{a}}$ & Model 1 & Model 2a & Model $3^{a}$ \\
\hline & \multicolumn{6}{|c|}{ Estonia } \\
\hline \multicolumn{7}{|l|}{ Education - Higher (ref.) } \\
\hline Basic & $5.69^{\star * *}$ & $5.98^{\star \star *}$ & $3.82^{\star * \star}$ & $3.94^{* * *}$ & $3.20^{* * *}$ & $2.58^{*}$ \\
\hline Secondary & $2.92^{* * *}$ & $2.82^{* * *}$ & $2.23^{* * *}$ & $1.67^{*}$ & $1.67^{*}$ & 1.54 \\
\hline \multicolumn{7}{|c|}{ Employment status - Non-working (ref.) } \\
\hline Employed white-collar & & & $0.48^{* * *}$ & & & $0.54^{*}$ \\
\hline Employed blue-collar & & & 0.86 & & & $0.61^{+}$ \\
\hline \multicolumn{7}{|c|}{ Self-rated financial situation - Good (ref.) } \\
\hline Poor & & & $2.05^{\star * *}$ & & & 1.18 \\
\hline \multirow[t]{2}{*}{$\mathrm{R}^{2}$} & $0.101^{* \star *}$ & $0.231^{* * *}$ & $0.283^{\star * \star}$ & $0.051^{\star \star *}$ & $0.189^{* \star *}$ & $0.205^{\star * *}$ \\
\hline & \multicolumn{6}{|c|}{ Russia } \\
\hline \multicolumn{7}{|l|}{ Education - Higher (ref.) } \\
\hline Basic & $1.84^{+}$ & 1.53 & 1.11 & $2.08^{*}$ & 1.73 & 1.24 \\
\hline Secondary & $1.91^{* * *}$ & $1.40^{*}$ & 1.23 & $1.31^{+}$ & 1.23 & 0.98 \\
\hline \multicolumn{7}{|c|}{ Employment status - Non-working (ref.) } \\
\hline Employed white-collar & & & 0.90 & & & 0.83 \\
\hline Employed blue-collar & & & 1.04 & & & 0.80 \\
\hline \multicolumn{7}{|c|}{ Self-rated financial situation - Good (ref.) } \\
\hline Poor & & & $2.41^{* * *}$ & & & $2.66^{* * *}$ \\
\hline \multirow[t]{2}{*}{$\mathrm{R}^{2}$} & $0.028^{* * *}$ & $0.177^{\star \star *}$ & $0.216^{\star \star *}$ & $0.011^{*}$ & $0.174^{* \star *}$ & $0.229^{* \star *}$ \\
\hline & \multicolumn{6}{|c|}{ Finland } \\
\hline \multicolumn{7}{|l|}{ Education - Higher (ref) } \\
\hline Basic & $8.67^{* * *}$ & $4.39^{* * *}$ & $3.24^{* * *}$ & $5.14^{* * *}$ & $2.89^{* * *}$ & $1.80^{+}$ \\
\hline Secondary & $3.88^{* * *}$ & $2.71^{* * *}$ & $2.55^{\star * *}$ & $2.60^{* * *}$ & $2.23^{* *}$ & $1.74^{*}$ \\
\hline \multicolumn{7}{|c|}{ Employment status - Non-working (ref.) } \\
\hline Employed white-collar & & & $0.45^{\star * *}$ & & & $0.29^{* * *}$ \\
\hline Employed blue-collar & & & 1.03 & & & $0.48^{* *}$ \\
\hline \multicolumn{7}{|c|}{ Self-rated financial situation - Good (ref.) } \\
\hline Poor & & & $2.82^{* * *}$ & & & $1.72^{*}$ \\
\hline $\mathrm{R}^{2}$ & $0.137^{\star \star *}$ & $0.208^{* * *}$ & $0.274^{* \star *}$ & $0.085^{\star * \star}$ & $0.191^{* * *}$ & $0.258^{\star \star *}$ \\
\hline
\end{tabular}

a In addition to data presented in Table, model is adjusted for control variables (age, marital status, place of residence)

${ }^{+} \mathrm{p}<0.1,{ }^{*} \mathrm{p}<0.05,{ }^{* *} \mathrm{p}<0.01,{ }^{* * *} \mathrm{p}<0.001$ 
and highest for women in Estonia and Finland). Adjustment to age, marital status and place of residence (Model 2) had different consequences for educational inequalities in SRH in examined countries. The most important issue was whether and how main effect of education was mediated by age. Comparison of OR and $\mathrm{R}^{2}$ of Model 2 with Model 1 indicated that impacts of education and age on SRH were practically independent in Estonia, partly coinciding in Finland, while age impact was prevalent in Russia. It explained equalisation of gross adjusted educational health inequalities between Russia and Finland revealed in Table 3 (Model 2).

Knowledge-related (net) effect of education (presented in Model 3 as adjusted also to controls as well as to employment status and self-rated financial situation) varied by countries and gender groups. However, Estonian situation was rather similar to that in Finland, while Russia was clearly different. Education had no knowledge-related effect on SRH in Russia for both men and women alike. At the same time such educational health equality coincided with substantial health differentiation according to self-rated financial situation. It holds true for both gender groups of Russians. Contrary, in Estonia (similarly to Finland) patterns were gender-specific: knowledge-related impact of education was strong among women, while weak among men. Education in Estonia and Finland for both women and men seemed to exert some socio-economic effect as providing access to economic resources (impact of education in Model 2 decreased in Model 3 being adjusted to employment status and self-rated financial situation). Importance of economic resources as factors of lessthan-good SRH was gender-specific: both employment status and self-rated financial situation equally mattered for Estonian and Finnish women, while employment status was of greater importance than financial situation for men in both countries.

\section{DISCUSSION}

Results of this study were in line with previous studies that documented the existence of linkage between types of welfare states and level of self-rated health: in Finland as in a Scandinavian country people tend to report their health to be better than in post-socialist Estonia and Russian Federation. With regard to educational inequalities in risk of less-than-good health perception, picture was more complex. Magnitude and patterns of educational health inequalities were very similar in Estonia and Finland for both men and women. These results were in line with previous comparisons of Finland and Estonia (28). At the same time, comparison of these two cases is not enough to jump to conclusions about similarity of educational inequalities in Scandinavian and post-socialist countries. Including Russia into comparison once again supported the claim that results of comparisons of welfare state types depend partly on countries selected to represent these types. With regard to educational health inequality, conclusion of Eikemo et al. (14) that countries in the Scandinavian welfare regime are ranked less favourable than those in Eastern European regimes, seems to be supported by results of our comparison of Russia and Finland, but not by comparison of Estonia with Finland. Both gross educational health inequalities as well as knowledge-related educational inequalities were lower in Russia compared with Finland. But Russian case was rather about shared risks ('less-than-good health for all educational groups') than about shared opportunities for good health. Russian people with lower levels of education are exposed to risk of bad health to the substantially higher extent than analogous groups in Finland. Moreover, our analysis showed that contrary to Estonia and Finland, education was of quite limited predictive power of SRH in Russia. Russians perceived their health to be crucially dependent on their financial situation. It means that comparative analysis of income-related poor health risks in Estonia, Russia and Finland would provide us with totally different results with regard to health inequalities.

Our results only partly proved our suggestion that educational knowledge-related inequalities in SRH might be lower in Russia and Estonia compared with Finland because of prevailing socio-economic effect of education on health in these countries. This suggestion turned to be true in case of Russia, but not for Estonia. Possible reasons for unproved expectations might be a lack of attention paid to educational inequalities in terms of access to social resources and to competitiveness in the labour market, i.e. to what extent education provide a tool against uncertainty and prevent work- and unemployment-related stress. Previous research has revealed that cross-national variations in labour market outcomes are source of different magnitude of educational health inequalities (4). Series of comparative case studies revealing links between certain institutional packages (welfare state, education, labour market, public health) and socio-economic and knowledge-related effects of education on health inequalities would be of special interest. It would form the basis for such explanations of Scandinavian paradox that focus on particular linkages between certain institutions, certain policies or measures and related health outcomes (18).

\section{REFERENCES}

1. Costa-Font J, Hernández-Quevedo C. Measuring inequalities in health: what do we know? What do we need to know? Health Policy. 2012 Jul;106(2):195-206.

2. Duncan GJ, Daly MC, McDonough P, Williams DR. Optimal indicators of socioeconomic status for health research. Am J Public Health. 2002 Jul;92(7):1151-7.

3. Geyer S, Hemström Ö, Peter R, Vågerö D. Education, income, and occupational class cannot be used interchangeably in social epidemiology. Empirical evidence against a common practice. J Epidemiol Community Health. 2006 Sep;60(9):804-10.

4. Gesthuizen M, Huijts T, Kraaykamp G. Explaining health marginalisation of the lower educated: the role of cross-national variations in health expenditure and labour market conditions. Sociol Health Illn. 2012 May;34(4):591-607.

5. Davey Smith G, Hart C, Hole D, MacKinnon P, Gillis C, Watt G, et al. Education and occupational social class: which is the more important indicator of mortality risk? J Epidemiol Community Health. 1998 Mar;52(3):153-60.

6. Bessudnov A, McKee M, Stuckler D. Inequalities in male mortality by occupational class, perceived status and education in Russia, 1994-2006. Eur J Public Health. 2012 Jun;22(3):332-7.

7. Leinonen T, Martikainen P, Lahelma E. Interrelationships between education, occupational social class, and income as determinants of disability retirement. Scand J Public Health. 2012 Mar;40(2):157-66.

8. Mirowsky J, Ross CE. Education, social status, and health. New York: A. de Gruyter; 2003.

9. Hill TD, Needham BL. Gender-specific trends in educational attainment and self-rated health, 1972-2002. Am J Public Health. 2006 Jul;96(7):1288-92.

10. Navarro V, editor. The Political and social contexts of health. Amityville, NY: Baywood; 2004. 
11. Beckfield J, Krieger N. Epi + demos + cracy: linking political systems and priorities to the magnitude of health inequities - evidence, gaps, and a research agenda. Epidemiol Rev. 2009;31:152-77.

12. Kaplan GA. Health inequalities and the welfare state: perspectives from social epidemiology. Nor Epidemiol. 2007;17(1):9-20.

13. Mackenbach JP. The persistence of health inequalities in modern welfare states: the explanation of a paradox. Soc Sci Med. 2012 Aug;75(4):761-9.

14. Eikemo TA, Bambra C, Joyce K, Dahl E. Welfare state regimes and income-related health inequalities: a comparison of 23 European countries. Eur J Public Health. 2008 Dec;18(6):593-9.

15. Huijts T, Monden CWS, Kraaykamp G. Education, educational heterogamy, and self-assessed health in Europe: a multilevel study of spousal effects in 29 European countries. Eur Sociol Rev. 2010;26(3):261-76.

16. Richter M, Rathman K, Nic Gabhainn S, Zambon A, Boyce W, Hurrelmann $\mathrm{K}$. Welfare state regimes, health and health inequalities in adolescence: a multilevel study in 32 countries. Sociol Health Illn. 2012 Jul;34(6):858-79.

17. Muntaner C, Borrell C, Ng E, Chung H, Espelt A, Rodriguez-Sanz M, et al. Politics, welfare regimes, and population health: controversies and evidence. Sociol Health Illn. 2011 Sep;33(6):946-64.

18. Lahelma E, Lundberg O. Health inequalities in European welfare states. Eur J Public Health. 2009 Oct;19(5):445-6.

19. Lane D, Myant M, editors. Varieties of capitalism in post-communist countries. Basingstoke: Palgrave Macmillan; 2007.

20. Lauristin M, Vihalemm P, Rosengren KE, Weibull L, editors. Return to the Western world: cultural and political perspectives on the Estonian post-communist transition. Tartu: Tartu University Press; 1997.

21. Saar E, editor. Towards a normal stratification order: actual and perceived social stratification in post-socialist Estonia. Frankfurt am Main: Peter Lang; 2011.
22. World Bank. World development indicators 2011 [Internet]. Washington: World Bank; 2011 [cited 2011 May 15]. Available from: http://siteresources.worldbank.org/DATASTATISTICS/Resources/wdi_ebook.pdf.

23. Organization for Economic Co-operation and Development. OECD Reviews of labor market and social policies: Russian Federation 2011. OECD Publishing; 2012.

24. European Social Survey. Data and documentation by round/year. Round 5 (2010) [Internet]. London: ESS [cited 2014 Jun 3]. Available from: http://www.europeansocialsurvey.org./data/round-index.html.

25. European Social Survey. ESS5 - 2010 Documentation Report. Ed. 3.2 [Internet]. Bergen: The ESS Data Archive, NSD; 2014 [cited 2014 Jun 3]. Available from: http://www.europeansocialsurvey.org./docs/round5/ survey/ESS5 data documentation report e03 2.pdf.

26. Carlson P. Risk behaviours and self rated health in Russia 1998. J Epidemiol Community Health. 2001 Nov;55(11):806-17.

27. Gilmore AB, McKee M, Rose R. Determinants of and inequalities in self-perceived health in Ukraine. Soc Sci Med. 2002 Dec;55(12):2177-88.

28. Pärna K, Ringmets I. Comparison of socioeconomic differences in selfperceived health in Estonia and Finland. Scand J Public Health. 2010 Mar;38(2):129-34

29. Commission on Social Determinants of Health. Closing the gap in a generation: health equity through action on the social determinants of health. Final Report of the Commission on Social Determinants of Health. Geneva: WHO; 2008 .

30. Lynch J, Kaplan G. Socioeconomic position. In: Berkman LF, Kawach I, editors. Social epidemiology. Oxford: Oxford University Press; 2000. p. 13-35.

Received June 3, 2013 Accepted in revised form June 3, 2014 